\title{
Yem Bezelyesi Silajlarında Karbonhidrat Kaynağı Olarak Melas Kullanılma Olanakları
}

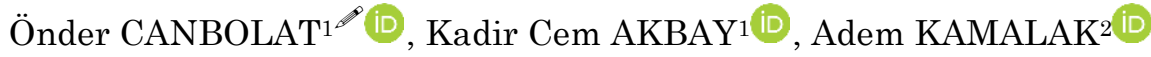 \\ ${ }^{1}$ Bursa Uludağ Üniversitesi Ziraat Fakültesi Zootekni Bölümü, Nilüfer/Bursa, ${ }^{2}$ Kahramanmaraş Sütçü İmam Üniversitesi Ziraat Fakültesi \\ Zootekni Bölümü, Avşar/Kahramanmaraş \\ 凹: onder@uludag.edu.tr
}

\section{ÖZET}

Bu araştırma, yem bezelyesi (Pisum Sativum L.) silajına suda çözünür karbonhidrat (ŞÇK) kaynağ 1 olarak melas ilavesinin silo fermantasyonu, mikrobiyolojisi, in vitro gaz üretimi ve nispi yem değerleri (NYD) üzerine etkilerini saptamak için düzenlenmiştir. $\mathrm{Bu}$ amaçla yem bezelyesi bakla doldurma döneminde hasat edilmiştir. Hasat sonrası yaklaşı $1.5-2.0 \mathrm{~cm}$ boyutunda parçalanan taze materyale 0 (kontrol), 15, 30, 45 ve $60 \mathrm{~g} / \mathrm{kg}$ taze materyal (TM) düzeyinde melas katılmıştır.

Melas ilavesi yem bezelyesi silajlarının ham besin maddeleri bileşimini önemli derecede etkilemiştir $(\mathrm{P}<0.01)$. Melas dozuna bağl olarak silajların ham protein (HP), ham yağ (HY), nötr deterjan lif (NDF), asit deterjan lif (ADF) ve asit deterjan lignin (ADL) içeriği azalmış, kuru madde (KM), ham kül (HK) ve suda çözünebilir karbonhidrat $(\mathrm{SCCK})$ içeriği artmıştır $(\mathrm{P}<0.01)$. Melas ilavesi yem bezelyesi silajlarının $\mathrm{pH}$ 'sını, asetik asit, bütirik asit ve amonyak azotu $\left(\mathrm{NH}_{3}-\mathrm{N}\right)$ içeriklerini düşürürken, laktik asit ve propiyonik asit içeriklerini artırmıştır $(\mathrm{P}<0.01)$. Aynı şekilde melas ilavesi yem bezelyesi silajlarının in vitro gaz üretimi, organik madde sindirim derecesini (OMSD) ve metabolik enerji (ME) içeriklerini de artırmıştır $(\mathrm{P}<0.01)$. Melas ilavesi ayrıca yem bezelyesi silajlarının nispi yem değeri (NYD) ve kuru madde tüketimi (KMT)'ni olumlu yönde etkilemiştir $(\mathrm{P}<0.01)$.

Araştırma sonucunda, melasın SÇK düzeyi düşük olan yem bezelyesi silajlarında kullanılması, silajların yem değerini ve fermantasyon özelliklerini iyileştirmiş̧tir.

\section{Possibilities of Use of Molasses as Carbohydrate Source in Pea Silages}

\section{ABSTRACT}

This research was designed to determine the effects of molasses supplementation as a water-soluble carbohydrate source on silo fermentation, microbiology, in vitro gas production and relative feed values of pea (Pisum Sativum L.) silage. For this purpose, pea plant was harvested during the pod period. After harvesting, they were crushed to a size of $1.5-2.0 \mathrm{~cm}$ and molasses were added at 0 (control), $15,30,45$ and $60 \mathrm{~g} / \mathrm{kg}$ fresh material, respectively.

Molasses supplementation affected $(\mathrm{P}<0.01)$ the composition of nutrients of pea silage. Depending on level of molasses supplementation, crude protein, crude oil, neutral detergent fiber, acid detergent fiber and acid detergent lignin contents of pea silage decreased, dry matter, crude ash and water soluble carbohydrate contents of pea silage increased $(\mathrm{P}<0.01)$. Molasses supplementation decreased $\mathrm{pH}$, acetic acid, butyric acid and ammonia nitrogen contents of pea silage, whereas lactic acid and propionic acid contents of pea silage increased $(\mathrm{P}<0.01)$. Likewise, the supplementation of molasses increased $(\mathrm{P}<0.01)$ in vitro gas production, organic matter digestibility and metabolizable energy contents of pea silage. In addition, molasses
Makale Tarihçesi

Geliş Tarihi: 29.08.2018

Kabul Tarihi : 01.10.2018

Anahtar Kelimeler

Yem bezelyesi,

melas,

silaj fermantasyonu, in vitro gaz üretimi, nispi yem değeri

\section{Araştırma Makalesi}

\section{Article History}

Received : 29.08.2018

Accepted : 01.10.2018

\section{Keywords \\ Fed peas, \\ molasses, \\ silage fermentation, \\ in vitro gas production, \\ relative feed value}

Research Article 
supplementation positively affected $(\mathrm{P}<0.01)$ the relative feed value and dry matter intake of pea silages.

As a result of the research, the use of molasses in water soluble carbohydrate (WSC) insufficient pea silage, improved the feed value and fermentation characteristics of pea silages.

To Cite: Canbolat Ö, Akbay KC, Kamalak A 2019. Yem Bezelyesi Silajlarında Karbonhidrat Kaynağı Olarak Melas Kullanılma Olanakları. KSÜ Tar Doğa Derg 22(1) : 122-130, DOI : 10.18016/ksutarimdoga.vi.455713.

\section{GİRİ̧}

Son yıllarda Türkiye'de görülen ekonomik gelişmeler ile insan sayısındaki artış hayvansal ürün talebini artırmıştır. Arzu edilen hayvansal ürün ihtiyacının karşılanmak ve hayvanlardan beklenen verimin alınmasında en önemli girdi faktörünü (\%65-70) yem ham maddeleri oluşturmaktadır (Boğa 2014). Özellikle ruminant beslemede en önemli yem ham maddelerinin başında kaliteli kaba yem gelmektedir. Hayvan beslemede kaliteli kaba yemler, ucuz bir kaynak olması, ruminantlarda rumen mikro flora ve faunasının gelişimi için gerekli (protein, yağ, selüloz, mineral ve vitaminleri) besin unsurlarını sağlaması, hayvanların verimlerinin artırılması, beslemeye bağlı metabolik hastalıkları önlemesi ve yüksek kalitede hayvansal ürün için önemlidirler (Alçiçek ve Karaayvaz 2003).

Kaliteli kaba yem kaynaklarından bir tanesi de yem bezelyesidir (Pisum Sativum L.) (Ay ve ark., 2017). Yem bezelyesi besin madde bileşimi açışından diğer kaba yemlerden oransal olarak yüksek ham protein (Blagojević ve ark., 2017; Yavuz 2017) ve oransal olarak düşük suda çözünebilir karbonhidrat içeriğine sahiptir (McDonald ve ark., 1991; Borreani ve ark., 2006). Baklagil kaba yemleri hem kuru ot olarak hem de silolanarak hayvan beslemede kullanılmaktadırlar. Yem bezelyesi gibi ham protein, mineral madde ve tampon madde içeriği yüksek (McDonald ve ark., 1991; Rooke ve Hatfield 2003), suda çözünebilir karbonhidrat içeriğini düşük (Borreani ve ark., 2006) yemlerin silolanması aşamasında silaj fermantasyonunu geliştirmek için katkı maddelerine gereksinim duyulmaktadır (Rooke ve Hatfield 2003; Kaiser 2004; Ni ve ark., 2017). Bu katkı maddelerinden özellikle fermantasyonu uyarıcı karbonhidrat kaynakları ön plana çıkmaktadır (Kaiser 2004). Bu amaçla kullanılan karbonhidrat (özellikle kolay çözünebilir karbonhidrat) maddelerden birisi melastır (Tjandraatmadja ve ark., 1994; Kaiser 2004; Li ve ark., 2014; Ni ve ark., 2017).

Şeker pancarından elde edilen melas yaklaşık \%70-75 kuru madde ve kuru madde de \%83-85 suda çözünebilir karbonhidrat (SÇK) (çoğunlukla sakaroz) içeriğine sahiptir. Özgül ağırlığı ise $1.4 \mathrm{~kg} / \mathrm{L}$ 'dir. Yapılan araştırmalarda melasin silajlara hasat edildiği andaki materyale 20-60 kg/ton arasında katılması önerilmektedir (Kaiser 2004).
$\mathrm{Bu}$ çalışma yem bezelyesi silajlarına SÇK kaynağı olarak melas ilavesinin silajlarin fermantasyonu, mikrobiyolojik özellikleri, in vitro gaz üretimi ile nispi yem değeri üzerine olan etkilerinin saptanmayı amaçlanmıştır.

\section{MATERYAL ve METOT}

Yem materyali ve silolar

Araştırmada yem materyali olarak yem bezelyesi (Pisum Sativum L.) ile yem bezelyesinin kolay çözünebilir karbonhidrat içeriğini artırmak için ise melas kullanılmıştır. Yem bezelyesinin silolanması için yalnızca gaz çıkışına olanak tanıyan $1.5 \mathrm{~L}$ özel anaerobik cam silolar (Weck ${ }^{\circledR}, \quad$ Germany) kullanılmıştır.

\section{Hayvan materyali}

In vitro gaz üretim tekniğinin uygulanması amacıyla 3 baş rumen kanüllü Kıvırcık koç kullanılmıştır. Hayvanlar yonca kuru otu (\%60) yoğun yem karması (\%40) (\%18 ham protein, $2750 \mathrm{kcal} / \mathrm{kg} \mathrm{KM})$ temeline dayanan rasyonla yemlenmişler ve hayvanların önlerinde sürekli içme suyu bulundurulmuştur.

\section{Silajların hazırlanması}

Araştırmada kullanılan yem bezelyesi yaklaşık 1.5-2.0 $\mathrm{cm}$ boyutlarında parçalanmıştır. Parçalanan yem bezelyesine sirasiyla $\% 0$ (kontrol), $15,30,45$, ve $60 \mathrm{~g} / \mathrm{kg}$ $\mathrm{KM}$ oranında melas ilave edilmiş ve böylece 5 farklı silaj grubu oluşturulmuştur. Yem bezelyesine melas uygulaması sırasında her defasında $15 \mathrm{~kg}$ parçalanmış yem bezelyesi temiz bir yere yayılmış ve üzerine melas pulverize edilerek homojen bir şekilde karıştırılmıştır. Daha sonra anaerobik silolara her birinden 5 tekrar olacak şekilde silolanmıştır. Silolar 60 gün boyunca laboratuar koşullarında tutulmuştur. $\mathrm{Bu}$ süre sonunda açılan silajların kimyasal analizleri, mikrobiyolojik özellikleri, in vitro gaz üretimi, OMSD, ME ve NYD'leri saptanmıştır.

\section{İn vitro gaz üretim tekniğinin uygulanması}

Yem ham maddelerinin in vitro koşullarda OMSD ve ME değerlerinin saptanmasında Menke ve Steingass (1988) tarafindan bildirilen "in vitro gaz üretim tekniğ̣i" kullanılmıştır. Yem ham maddelerinin gaz üretim miktarlarının saptanmasında $100 \mathrm{ml}$ hacimli özel cam tüplere (Model Fortuna, Häberle Labortechnik, Lonsee-Ettlenschieß, Germany) üç 
paralel olacak şekilde yaklaşık $200 \pm 10 \mathrm{mg}$ yem örneği konmuştur. Daha sonra üzerine Menke ve ark. (1979) tarafından bildirilen yönteme göre hazırlanan tamponlanmış rumen sıvısı çözeltisinden $30 \mathrm{ml}$ ilave edilmiştir. $\mathrm{Bu}$ işlemden sonra tüpler $39^{\circ} \mathrm{C}$ 'de ki su banyosunda inkübasyona alınmışlar ve sırasıyla 3,6 , $12,24,48,72$ ve 96 . saatlerde fermantasyonla oluşan gaz miktarları saptanmıştır.

Silajların ME ve OMSD değerleri Menke ve Steingass (1988) tarafindan bildirilen aşağıdaki eşitliklerle saptanmıştır.

OMSD $\%=15.38+0.8453 \times$ GÜ $+0.0595 \times \mathrm{HP}+0.0675$ $\mathrm{x}$ HK

$\mathrm{ME}, \mathrm{MJ} / \mathrm{kg} \mathrm{KM}=2.20+0.1357 \times \mathrm{GÜ}+0.0057 \times \mathrm{HP}+$ $0.0002859 \times \mathrm{HY}^{2}$

(GÜ: 200 mg kuru yem örneğinin 24 saat inkübasyon süresi sonundaki net gaz üretimi, HP: \%ham protein, HY: \%ham yağ ve HK: \%ham kül).

\section{Nispi yem değerinin saptanması}

Nispi yem değeri Rohweder ve ark. (1978) tarafından geliştirilen aşağıdaki eşitlikler ile saptanmıştır. Nispi yem değerini hesaplamak için öncelikle kuru madde sindirimi (\%KMS) ADF değerinden hesaplanmaktadır.

$$
\% K M S=88.9-\left(0.779_{X} \% A D F\right)
$$

Hayvanın canlı ağırlı̆̆ına bağlı olarak kuru madde tüketimi (\%KMT) NDF değerinden hesaplanmaktadır.

\section{$\% K M T=120 / N D F$}

Nispi yem değerini hesaplamak için \%KMS ve \%KMT değerleri formülde yerine konulur.

$N Y D=\% K M S_{x} \% K M T \times \quad 0.775$

Nispi yem değeri yemlerin bileşiminde \%41 ADF ve \%53 NDF olduğunda 100 olarak standart kabul edilir (Rohweder ve ark., 1978). Bu değerin 100'den büyük olması yemin kalitesinin yüksek olmasına, düşük olması ise yemin kalitesinin düşük olduğunun bir göstergesi olarak kullanılmaktadır.

\section{Kimyasal analizler}

Yem bezelyesi silajları $65^{\circ} \mathrm{C}$ 'de etüvde 48 saat süreyle kurutulmuş ve $1 \mathrm{~mm}$ elek çapına sahip değirmende öğüülerek kimyasal analizlerde kullanılmıştır. Yemlerin kuru madde (KM) içeriği $105^{\circ} \mathrm{C}$ 'de etüvde 3 saat kurutularak, ham kül içeriği $550^{\circ} \mathrm{C}^{\prime}$ de 4 saat kül firınında yakılarak, ham yağ analizi eter ekstraksiyonu yöntemi ile belirlenmiştir (AOAC 2000). Ham protein analizi AOAC (2000)'de bildirildiği gibi Kjeldahl metoduna göre yapılmıştır. Yemlerin NDF, ADF ve ADL içerikleri ise Van Soest ve ark. (1991) tarafindan bildirilen yöntemlere göre ANKOM 200 Fiber Analyzer (ANKOM, USA) ile belirlenmiştir.

Silajların pH'sı dijital pH metre cihazı (Sartorius PB20 , Goettingen, Germany) ile amonyak azotu $\left(\mathrm{NH}_{3}-\mathrm{N}\right)$ içerikleri AOAC (2000)'ye göre yapılmıştır. Asetik, propiyonik ve bütirik asit içerikleri gaz kromotografi cihazı (Agilent Technologies 6890N, kolon özellikleri: Stabilwax-DA, $30 \mathrm{~m}, 0.25 \mathrm{~mm}$ ID, $0.25 \mathrm{um}$ df. Max. temp: $260^{\circ} \mathrm{C}$. Cat. 11023$)$ ile laktik asit analizi ise spectrofotometrik yöntemle (Barker ve Summerson 1941), suda çözünebilir karbonhidrat (SÇK) içerikleri fenol sülfürik asit yöntemine (Dubois ve ark., 1956) göre belirlenmiştir.

Silajların yapısındaki laktik asit bakterileri, maya ve küf sayımları Seale ve ark. (1990) tarafından bildirilen yöntemler doğrultusunda gerçekleştirilmiştir. Buna göre ekim ortamı olarak LAB için MRS agar, maya ve küfler için Malt Ekstrat agar kullanılmıştır. Örneklere ait LAB, maya ve küf sayımları $30^{\circ} \mathrm{C}$ sicaklıkta 3 günlük inkübasyon dönemlerini takiben yapılmıştır. Örneklerde saptanan LAB, maya ve küf sayıları logaritma koliform ünite (cfu)/g'ye çevrilerek verilmiş̧tir.

\section{İstatistik analizler}

Araştırmadan elde edilen veriler varyans analizine tabi tutulmuş olup ortalamalar arasındaki farklar Duncan çoklu karşılaştırma testiyle belirlenmiştir (SAS 2004).

\section{BULGULAR ve TARTIŞMA}

Yem ham maddeleri ve silajların kimyasal bileşimleri Yem bezelyesi, melas ve yem bezelyesi silajlarının kimyasal analiz sonuçları saptanmış ve Çizelge 1'de verilmiştir.

Araştırmada kullanılan melas katkısı yem bezelyesi silajlarının KM içeriğini artırmıştır $(\mathrm{P}<0.01)$. En yüksek KM \%31.73 ile $60 \mathrm{~g} / \mathrm{kg}$ TM melas ilaveli bezelye silajında gerçekleşmiştir. Yem bezelyesine melas ilavesinin artışına bağlı HP içeriği \%16.77-16.09 arasında değişmiş ve melas dozları arası farklılıklar önemli bulunmuştur $(\mathrm{P}<0.01)$. Melas ilavesinin artışına bağlı olarak ham protein içeriği düşmüş ve en düşük HP değeri 40 ila $60 \mathrm{~g} / \mathrm{kg}$ TM melash gruplarda saptanmıştır. Yem bezelyesine melas ilavesinin HP içeriğini düşürmesi melasın HP içeriğinin düşük (\%11.32 KM) olmasının bir sonucudur. Yem bezelyesi HP düzeyi Tyrolová ve Výborná (2011)'in bildirmiş oldukları değerlerden yüksek, Bastida Garcia ve ark. (2011), Kocer ve Albayrak (2012) ve Yavuz (2017'un bildirmiş oldukları değerlerle benzer bulunmuştur.

Yem bezelyesi silajlarının HK içeriği \%6.17 ile 6.35 arasında değişmiş ve en yüksek $60 \mathrm{~g} / \mathrm{kg}$ TM melas ilaveli bezelye silajında bulunmuştur. Melasın yapısında HK (\%7.12)'ün yüksek olması melas ilavesine bağlı olarak silajların HK içeriğini artırmıştır $(\mathrm{P}<0.01)$. Yem bezelyesi HK içeriği Göçmen ve Özaslan Parlar (2017), ve Wamatu ve ark. (2017) bildirdiği değerlerden düşük bulunmuştur.

Yem bezelyesi silajlarının NDF, ADF ve ADL içerikleri sirasiyla; \%39.12-36.19, \%30.17-26.16 ve \%13.38-12.48 arasında değişmiştir. 
Çizelge 1. Yem bezelyesi, melas ve yem bezelyesi silajlarına melas ilavesinin ham besin maddeleri bileşimine (\%) etkisi

\begin{tabular}{|c|c|c|c|c|c|c|c|c|}
\hline \multirow[b]{2}{*}{ Besin unsurları } & \multirow[b]{2}{*}{ TM } & \multirow[b]{2}{*}{ Melas } & \multicolumn{6}{|c|}{ Melas Katkı Oranı ( g/kg TM) } \\
\hline & & & 0 & 15 & 30 & 45 & 60 & SHO \\
\hline KM & 27.51 & 73.15 & $27.72^{\mathrm{c}}$ & $28.19^{\mathrm{c}}$ & $29.67^{\mathrm{b}}$ & $30.44^{b}$ & $31.73^{\mathrm{a}}$ & 0.311 \\
\hline $\mathrm{OM}$ & 93.85 & 92.88 & $93.85^{\mathrm{a}}$ & $93.79^{\mathrm{a}}$ & $93.73^{\mathrm{a}}$ & $93.71^{\mathrm{a}}$ & $93.65^{\mathrm{a}}$ & 0.298 \\
\hline $\mathrm{HP}$ & 16.74 & 11.32 & $16.77^{\mathrm{a}}$ & $16.45^{\mathrm{b}}$ & $16.39^{b}$ & $\begin{array}{l}16.24^{\mathrm{b}} \\
\mathrm{c}\end{array}$ & $16.09^{c}$ & 0.098 \\
\hline HK & 6.15 & 6.12 & $6.17^{\mathrm{d}}$ & $6.21^{\mathrm{c}}$ & $6.27^{\mathrm{b}}$ & $6.29^{\mathrm{b}}$ & $6.35^{\mathrm{a}}$ & 0.024 \\
\hline $\mathrm{HY}$ & 4.43 & -- & $4.48^{\mathrm{a}}$ & $4.26^{\mathrm{b}}$ & $4.21^{\mathrm{bc}}$ & $4.15^{\mathrm{c}}$ & $3.99^{\mathrm{c}}$ & 0.029 \\
\hline NDF & 40.11 & -- & $39.12^{\mathrm{a}}$ & $38.36^{\mathrm{a}}$ & $37.29^{\mathrm{b}}$ & $\begin{array}{l}36.91^{b} \\
c\end{array}$ & $36.19^{c}$ & 0,298 \\
\hline $\mathrm{ADF}$ & 31.24 & -- & $30.17^{\mathrm{a}}$ & $29.58^{\mathrm{b}}$ & $28.92^{\mathrm{c}}$ & $27.67^{\mathrm{d}}$ & $26.16^{\mathrm{e}}$ & 0.179 \\
\hline ADL & 13.46 & -- & $13.48^{\mathrm{a}}$ & $\begin{array}{l}13.29^{a} \\
b\end{array}$ & $12.93^{\mathrm{bc}}$ & $\begin{array}{l}12.86^{b} \\
c\end{array}$ & $12.48^{\mathrm{c}}$ & 0.201 \\
\hline SÇK & 4.21 & 78.57 & $1.77^{\mathrm{d}}$ & $2.25^{\mathrm{c}}$ & $2.89^{\mathrm{b}}$ & $3.26^{\mathrm{a}}$ & $3.38^{\mathrm{a}}$ & 0.136 \\
\hline
\end{tabular}

${ }_{a, b, c, d, e}$ Aynı sütunda farklı harfler ile gösterilen ortalamalar arasındaki farklllıklar önemlidir ( $\left.P<0.01\right)$. SHO standart hata;ortalaması, TM: Taze materyal; KM: kuru madde; OM: organik madde,; HP: ham protein; HK: ham kül; HY: ham yağ; NDF: nötr deterjanda çözünmeyen lif; ADF: asit deterjanda çözünmeyen lif; ADL: asit deterjanda çözünmeyen lignin; SCKK: suda çözünebilir karbonhidrat

Melas ilavesi silajlarmin NDF, $\mathrm{ADF}$ ve $\mathrm{ADL}$ içeriklerini önemli düzeyde düşürmüştür $(\mathrm{P}<0.01)$. Bu düşüşün temel nedeni melasin hücre duvarı bileşenlerini (NDF, ADF ve ADL vb.) içermemesi (Jian ve ark., 2017) ve ayrıca melas gibi SÇK kaynaklarının silo içinde bakteriyel faaliyetlerin artması sonucu bitki hücre duvarı bileşenlerinin parçalanması ile açıklanabilir (Limin Kung ve ark., 2003; Canbolat ve ark., 2010). Bolsen ve ark., (1996) ise silajların silo ortamında SÇK'ların laktik asit bakterileri ile birlikte bazı anaerobik bakterilerin saylarını artırarak, silajların NDF, ADF ve ham sellüloz parçalanabilirliğini hızlandırması NDF ve ADF gibi hücre duvarı bileşenlerinin azalmasına yol açtığını bildirmişlerdir. Bezer bulgular Canbolat ve ark. (2010) ve $\mathrm{Li}$ ve ark. (2014)'nın çalışmalarında da görülmüştür. Araştırmada saptanan NDF ve ADF düzeyleri Bastida Garcia ve ark. (2011)'nın bildirmiş oldukları değerlerden düşük, Kocer ve Albayrak (2012)'nın bildirdikleri sonuçlarla benzerlik göstermiştir.
Yem bezelyesi silajların SÇK içerikleri \%1.77-3.38 arasında değişmiş olup melas ilavesi silajların SÇK içeriğini önemli düzeyde artırmıştır $(\mathrm{P}<0.01)$. En yüksek SÇK içerikleri 40 ila $60 \mathrm{~g} / \mathrm{kg}$ TM melas katkılı silaj gruplarında saptanmıştır $(\mathrm{P}<0.01)$. Silo yemlerine melas ilavesinin silajların SÇK içeriğini artırması Tjandraatmadja ve ark. (1994) ve Limin Kung ve ark. (2003) ile Jian ve ark. (2017)'nın çalışmaları ile benzer bulunmuştur. Silo yemlerine melas ilavesinin SÇK içeriğini artması melasın yapısında yüksek düzeyde SÇK (\%78.57) bulunması ile açıklanabilir (Tjandraatmadja ve ark., 1994; Jian ve ark., 2017; Limin Kung ve ark., 2003). Yem bezelyesi silajlarının SÇK içerileri Borreani ve ark. (2006) ve Tyrolová ve Výborná (2011)'nın bildirdikleri sonuçlarla uyumlu alarak saptanmıştır.

\section{Silajların fermantasyon özellikleri}

Yem bezelyesine melas ilavesinin silaj fermantasyonu üzerine etkileri saptanmış ve Çizelge 2.'de verilmiştir.

Çizelge 2. Yem bezelyesi silajlarına melas ilavesinin silaj fermantasyonuna etkisi

\begin{tabular}{|c|c|c|c|c|c|c|}
\hline \multirow[b]{2}{*}{ Unsurlar } & \multicolumn{5}{|c|}{ Melas Katkı oranı, g/kg TM } & \multirow[b]{2}{*}{ SHO } \\
\hline & 0 & 15 & 30 & 45 & 60 & \\
\hline $\mathrm{pH}$ & $4.95^{\mathrm{a}}$ & $4.39^{\mathrm{b}}$ & $4.35^{\mathrm{b}}$ & $4.21^{\mathrm{c}}$ & $4.05^{\mathrm{d}}$ & 0.018 \\
\hline Laktik asit & $31.89^{\mathrm{c}}$ & $36.61^{\mathrm{b}}$ & $38.26^{\mathrm{b}}$ & $40.08^{\mathrm{ab}}$ & $42.28^{\mathrm{a}}$ & 1.544 \\
\hline Asetik asit & $22.57^{\mathrm{a}}$ & $17.21^{\mathrm{b}}$ & $16.91^{\mathrm{b}}$ & $15.36^{\mathrm{b}}$ & $15.06^{\mathrm{b}}$ & 1.352 \\
\hline Propiyonik asit & $0.18^{c}$ & $1.41^{\mathrm{b}}$ & $2.08^{\mathrm{a}}$ & $2.39^{\mathrm{a}}$ & $2.37^{\mathrm{a}}$ & 0.165 \\
\hline Bütirik asit & $0.64^{\mathrm{a}}$ & $0.57^{\mathrm{ab}}$ & $0.43^{\mathrm{abc}}$ & $0.40^{\mathrm{bc}}$ & $0.35^{\mathrm{c}}$ & 0.082 \\
\hline Etanol & $0.98^{\mathrm{c}}$ & $1.44^{\mathrm{bc}}$ & $1.85^{\mathrm{ab}}$ & $2.06^{\mathrm{a}}$ & $2.20^{\mathrm{a}}$ & 0.200 \\
\hline Amonyak azotu $\left(\mathrm{NH}_{3} \mathrm{~N}\right)$ & $1.22^{\mathrm{a}}$ & $1.12^{\mathrm{a}}$ & $1.10^{\mathrm{a}}$ & $0.89^{\mathrm{b}}$ & $0.85^{\mathrm{b}}$ & 0.052 \\
\hline
\end{tabular}

${ }_{a, b, c, d}$ Aynı sütunda farklı harfler ile gösterilen ortalamalar arasındaki farklılıklar önemlidir (P<0.01). SHO: standart hata ortalaması, TM: taze materyal; $\mathrm{NH}_{3}-\mathrm{N}$ : amonyak azotu ( $\mathrm{NH}_{3}-\mathrm{N}$ toplam $\mathrm{N}$ ' in \%' si olarak verilmiştir). 
Silaj kalite kriterleri arasında fermantasyon sırasında oluşan $\mathrm{pH}$, amonyak azotu $\left(\mathrm{NH}_{3} \mathrm{~N}\right)$ ve organik asitlerin miktarı ve bileşimleri son derece önemli olup, silaj fermantasyonu ve silaj kalitesini belirlemede kullanılan önemli parametrelerdir (McDonald ve ark., 1991; Limin Kung ve ark., 2003). Bu kalite kriterlerinden silaj pH'sı yem bezelyesine melas ilavesine bağlı olarak azalmış ve en düşük $60 \mathrm{~g} / \mathrm{kg}$ TM melaslı silaj gruplarda saptanmıştır $(\mathrm{P}<0.01)$. Melasın SÇK kaynağı olarak bezelye silajlarına ilavesi silo ortaminda laktik asit bakteri fermantasyonunu geliştirip, proteolosisi (proteinlerin amonyağa dönüşümünü) engelleyerek (McDonald ve ark., 1991; Limin Kung ve ark., 2003) silajlarmın pH düzeylerinin düşmesine neden olmuştur. Limin Kung ve ark. (2003) ve Jian ve ark. (2017) ile Ni ve ark. (2017) silajlara melas ilavesinin silaj $\mathrm{pH}$ 'sını düşürdüğünü bildirmişlerdir. Araştırmadan elde edilen bulgularda buna paralel olarak bulunmuştur.

Yem bezelyesine melas ilavesi silajlarm laktik asit içeriğini önemli düzeyde artırdığı tespit edilmiştir $(\mathrm{P}<0.01)$. En yüksek laktik asit içeriği $42.28 \mathrm{~g} / \mathrm{kg} \mathrm{KM}$ ile $60 \mathrm{~g} / \mathrm{kg}$ TM katılan yem bezelyesi silajinda, en düşük ise $31.89 \mathrm{~g} / \mathrm{kg}$ TM ile kontrol silajında saptanmıştır. Suda çözünebilir karbonhidrat içeriği yüksek melasın silaja katılması laktik asit bakterilerinin gelişmesini besin sağlayarak (glikoz, früktoz) teşvik etmiş ve böylece laktik asit üretiminin artmasına yol açmıştır (Limin Kung ve ark., 2003; Ni ve ark., 2017). Yem bezelyesi silajlarında SÇK içeriğinin artması silajlarda propiyonik asit düzeyini de artırmıştır $(\mathrm{P}<0.01)$. Umana ve ark. (1991) ile Jian ve ark. (2017)'ı yaptıkları çalışmalarda da laktik asit üretimini artırmış ve araştırma verileri ile uyumlu bulunmuştur. Silajlarda laktik ve propiyonik asit içeriğinin artması, asetik ve bütirik asit içeriğini düşürmüştür. En düşük asetik ve bütirik asit sırasıyla; $15.06 \mathrm{~g} / \mathrm{kg}$ TM ve $0.35 \mathrm{~g} / \mathrm{kg}$ TM ile $60 \mathrm{~g} / \mathrm{kg}$ TM melas katılan yem bezelyesi silajında saptanmış $(\mathrm{P}<0.01)$. Yem bezelyesine melas ilavesinin asetik asit ve bütirik asit içeriğinde azalmaya yol açması Umana ve ark. (1991) ve Jian ve ark. (2017) ile Ni ve ark. (2017)'nın bulguları ile uyumlu bulunmuştur.

Yem bezelyesi silajlarının toplam azot içerisindeki $\mathrm{NH}_{3}-\mathrm{N}$ düzeyi 1.22 ile $0.85 \mathrm{~g} / \mathrm{kg} \mathrm{TM}$ arasında değişmiş olup melas ilavesi silajların $\mathrm{NH}_{3}-\mathrm{N}$ 'u düzeyini önemli düzeyde düşürmüştür $(\mathrm{P}<0.01)$. Yem bezelyesine melas ilavesi silajların laktik asit ve propiyonik asit içeriğini artırmış, asetik ve bütirik asit içeriğini düşürerek proteolizi önlemiş ve bunun sonucu olarak silajların $\quad \mathrm{NH}_{3}-\mathrm{N}$ içeriğinin azaltmıştır (Tjandraatmadja ve ark., 1994; Limin Kung ve ark., 1991; Umana ve ark., 1991; Jian ve ark., 2017). Bu yolla silajlarda azot kaybı önlenmekte ve silaj kalitesi yükselmektedir. Yem bezelyesi silajının $\mathrm{NH}_{3}-\mathrm{N}$ içeriği yem bezelyesi ile çalışan Borreani ve ark. (2006)'nın bildirdikleri sonuçlarla benzer saptanmıştır

\section{Silajların mikrobiyolojik özellikleri}

Yem bezelyesine melas ilavesinin silajların mikrobiyolojik özellikleri üzerine etkileri saptanmış ve Çizelge 3.'de verilmiştir.

Çizelge 3. Yem bezelyesi silajlarına melas ilavesinin silaj mikrobiyolojik özelliklerine etkisi

\begin{tabular}{lllllll} 
& \multicolumn{7}{l}{ Melas Katkı Oranı, g/kg TM } & & \\
\cline { 2 - 6 } Unsurlar & 0 & 15 & 30 & 45 & 60 & $S H O$ \\
\hline LAB, log10 cfu/g TM & $5.67^{\mathrm{d}}$ & $7.47^{\mathrm{c}}$ & $9.61^{\mathrm{b}}$ & $10.56^{\mathrm{ab}}$ & $11.76^{\mathrm{a}}$ & 0.644 \\
Maya, log10 cfu/g TM & $1.34^{\mathrm{b}}$ & $1.35^{\mathrm{b}}$ & $1.44^{\mathrm{b}}$ & $1.89^{\mathrm{ab}}$ & $2.24^{\mathrm{a}}$ & 0.298 \\
Küf, $\log 10 \mathrm{cfu} / \mathrm{g}$ TM & $0.86^{\mathrm{a}}$ & $0.86^{\mathrm{a}}$ & $0.85^{\mathrm{a}}$ & $0.4^{\mathrm{ab}}$ & $0.13^{\mathrm{b}}$ & 0.227 \\
\hline
\end{tabular}

${ }_{a, b, c, d}$ Aynı sütunda farklı harfler ile gösterilen ortalamalar arasındaki farklılıklar önemlidir ( $\left.P<0.01\right) . *$ SS: standart hata ortalaması, TM: taze materyal; LAB: laktik asit bakterileri

Yem bezelyesine melas ilavesi LAB üretimini etkilemiş ve LAB sayısı 5.67 ile $11.76 \log 10 \mathrm{cfu} / \mathrm{g}$ TM arasında değişmiştir. Yem bezelyesine melas ilavesi LAB sayısını artırmış ve melas dozları arasındaki farklılıklar önemli bulunmuştur $(\mathrm{P}<0.01)$. En yüksek LAB $11.76 \log 10 \mathrm{cfu} / \mathrm{g}$ TM ile $60 \mathrm{~g} / \mathrm{kg}$ TM melas ilave edilen yonca silajında, en düşük melas ilave edilmeyen kontrol grubunda saptanmıştır. Laktik asit bakteri artış oranı 2.07 kat olmuştur. Yem bezelyesine melas kullanım dozunun artması silajların SÇK içeriğini artırmış, NDF ve ADF içeriğini düşürmüştür (Çizelge 1). Bu durum $L A B$ ve mayalar için daha fazla besin sağlayarak silaj pH'sını (Çizelge 1) LAB'nin üremesi için daha uygun hale gelmiş ve silo ortamında LAB üretimini artmıştır (Limin Kung ve ark., 2003). Yem bezelyesi silajında saptanan LAB sayısı farklı kaba yem (yonca) ve karbonhidrat (gladiçya meyvesi) kaynakları ile çalışan Kamalak ve ark. (2009)'nın bulguları ile farklı baklagil yemlerine melas ilave eden Tjandraatmadja ve ark. (1994)'nın bulgularından daha yüksek, Canbolat ve ark. (2013)'nın bulguları ile uyum içinde bulunmuştur. Laktik asit bakterileri yonca silajı ile çalışan Filya ve ark. (2001) ile soya silajına melas ilave eden Ni ve ark. (2017)'nın bildirdikleri değerlerle uyum içerisinde olduğu saptanmıştır.

Yem bezelyesi silajlarına melas katılması silajların maya sayısı artarmış, küf sayısını ise önemli düzeyde azaltmıştır $(\mathrm{P}<0.01)$. Yem bezelyesi silajlarının maya sayısı 0.99 ile $2.43 \quad \log 10 \quad \mathrm{cfu} / \mathrm{g} \quad$ TM arasinda değişmiştir. En yüksek maya sayısı $2.24 \log 10 \mathrm{cfu} / \mathrm{g}$ TM ile $60 \mathrm{~g} / \mathrm{kg}$ TM melas katılan yem bezelyesi silajında saptanmıştır. Yem bezelyesi silajlarına melas 
ilavesi sonucu maya oranındaki artışın melasın silaj ortamına sağladığı SÇK'ın mayalar için besin madde sağlamasından kaynaklandığı (Limin Kung ve ark., 2003) söylenebilir. Benzer bulgular yonca silajına SÇK kaynağı olarak gladiçya meyvesi kullanan Kamalak ve ark. (2009)' 1 ile Canbolat ve ark. (2013)'nın bildirdikleri sonuçlarla uyum içerisinde olduğu bulunmuştur. Yem bezelyesine melas ilave dozuna bağlı olarak küf sayısı önemli düzeyde azalmış ve en düşük küf miktarı $60 \mathrm{~g} / \mathrm{kg}$ TM melas ilave edilen silaj grubunda saptanmıştır. Silaja ilave edilen gladiçya meyvesinin silaj ortamında pH'yı düşürmesi ve LAB sayısını artırması küf sayısının azalmasına neden olmuştur (Canbolat ve ark., 2013). Araştırmadan elde edilen küf sayıları yonca silajına SÇK kaynağı olarak gladiçya meyvesi ile çalışan Kamalak ve ark. (2009)'dan yüksek, Canbolat ve ark. (2013)'nın bildirdikleri bulgularla uyum içerisinde olduğu saptanmıştır.

\section{Silajların in vitro gaz üretimi özellikleri}

Yem bezelyesi silajlarına melas ilavesinin silajların in vitro gaz üretimi, organik OMSD ve ME içerikleri üzerine etkileri saptanmış ve Çizelge 4'de verilmiştir.

Çizelge 4. Yem bezelyesi silajlarına melas ilavesinin silajların in vitro gaz üretimi (ml), organik madde sindirimi (\%) ve metabolik enerji içeriklerine (MJ/kg KM) etkisi

\begin{tabular}{lllllll}
\hline \multirow{2}{*}{ Inkübasyon süresi, saat } & \multicolumn{2}{l}{ Melas Katkı oranı, g/kg TM } & \multicolumn{3}{l}{ SHO } \\
\cline { 2 - 6 } & $\mathbf{0}$ & 15 & 30 & $\mathbf{4 5}$ & 60 & 0.628 \\
6 & $15.46^{\mathrm{d}}$ & $17.03^{\mathrm{cd}}$ & $18.10^{\mathrm{c}}$ & $19.76^{\mathrm{b}}$ & $21.83^{\mathrm{a}}$ & 0.951 \\
12 & $21.83^{\mathrm{c}}$ & $24.93^{\mathrm{b}}$ & $25.66^{\mathrm{b}}$ & $26.87^{\mathrm{ab}}$ & $28.80^{\mathrm{a}}$ & 0.917 \\
24 & $33.43^{\mathrm{d}}$ & $37.26^{\mathrm{c}}$ & $40.20^{\mathrm{b}}$ & $41.47^{\mathrm{ab}}$ & $43.30^{\mathrm{a}}$ & 0.917 \\
48 & $49.23^{\mathrm{c}}$ & $53.80^{\mathrm{b}}$ & $55.43^{\mathrm{b}}$ & $56.57^{\mathrm{ab}}$ & $59.3^{\mathrm{a}}$ & 1.322 \\
72 & $56.33^{\mathrm{c}}$ & $58.80^{\mathrm{c}}$ & $63.03^{\mathrm{b}}$ & $64.80^{\mathrm{ab}}$ & $66.57^{\mathrm{a}}$ & 1.014 \\
96 & $64.63^{\mathrm{c}}$ & $65.96^{\mathrm{c}}$ & $67.27^{\mathrm{c}}$ & $71.23^{\mathrm{b}}$ & $74.40^{\mathrm{a}}$ & 1.145 \\
\hline OMSD & $65.37^{\mathrm{c}}$ & $67.60^{\mathrm{c}}$ & $71.43^{\mathrm{b}}$ & $73.60^{\mathrm{b}}$ & $76.57^{\mathrm{a}}$ & 0.900 \\
ME & $58.29^{\mathrm{c}}$ & $62.12^{\mathrm{b}}$ & $63.49^{\mathrm{b}}$ & $64.44^{\mathrm{ab}}$ & $66.73^{\mathrm{a}}$ & 1.121 \\
\hline
\end{tabular}

$\overline{a, b, c, d}$ Aynı sütunda farklı harfler ile gösterilen ortalamalar arasındaki farklılıklar önemlidir (P<0.01); SHO: standart hata ortalaması, TM: taze materyal; OMSD: organik madde sindirim derecesi; ME: metabolik enerji

Yem bezelyesi silajlarma melas ilavesi in vitro gaz üretimini tüm inkübasyon sürelerinde önemli düzeyde etkilemiştir $(\mathrm{P}<0.01)$. Melas katılmış yem bezelyesi silajlarının 96 saatlik in vitro gaz üretimi 65.37 ile $76.57 \mathrm{ml}$ arasında değişmiştir. En yüksek gaz üretimi $76.57 \mathrm{ml}$ ile $60 \mathrm{~g} / \mathrm{kg}$ TM düzeyinde melas ilave edilen yem bezelyesi silajında, en düşük ise melas ilave edilmeyen kontrol silajında saptanmıştır. Yem bezelyesine ilave edilen melas silajların SÇK içeriğini artırarak, NDF ve ADF içeriğini düşürmüş (Çizelge 1) ve bunun sonucunda in vitro gaz üretimi artmıştır. Yem bezelyesi silajlarının in vitro gaz üretimi miktarları farklı kaba yem (yonca silajı) silajı ile çalışan ve SÇK kaynağı olarak üzüm posası kullanan Canbolat ve ark. (2010) ve aynı yeme SÇK kaynağı olarak gladiçya meyvesi kullanan Kamalak ve ark. (2009) ve Canbolat ve ark. (2013)'nın bulguları ile benzerlik gösterirken, kral otu silajına melas ilave eden Li ve ark. (2014)'nın bildirdikleri değerden daha yüksek olduğu saptanmıştır.

Yem bezelyesi silajlarına melas ilavesi silajların OMSD'ni önemli düzeyde etkilemiş ve melas dozları arasındaki farklılıklar önemli bulunmuştur $(\mathrm{P}<0.01)$. Silajların OMSD değerleri \%58.29 ile 66.73 arasında değişmiş, en yüksek \%66.73 ile $60 \mathrm{~g} / \mathrm{kg}$ TM düzeyinde melas ilave edilen yem bezelyesi silajında saptanmıştır. Yem bezelyesine melas ilavesi silajların
SÇK miktarını artırmış, NDF ve ADF gibi rumen ortamında çözünmesi zor olan bitki hücre duvarı bileşenlerini ise azaltmıştır. Bunun sonucu olarak OMSD'nin hesaplanmasında kullanılan 24. saatteki gaz üretimi yüksek saptanması OMSD'nin önemli düzeyde artmasına yol açtığı söylenebilir. Umana ve ark. (1991) silajlara melas ilavesinin in vitro sindirilebilirliği artırdığını bildirmişlerdir. Li ve ark. (2014) kral otu silajina melas ilavesinin yemlerin in vitro kuru madde sindirimini artırdığını saptamışlardır. Araştırmada saptanan OMSD'nin yem bezelyesi otu toplam sindirilebilir besin maddeleri ile çalışan Yavuz (2017)'un bildirdikleri sonuçlarla benzer saptanmiştır. Yem bezelyesi silajlarının OMSD değerleri farklı kaba yem (yonca silajı) silajı ile çalışan ve SÇK kaynağı olarak üzüm posası Canbolat ve ark. (2010) ve gladiçya meyvesi kullanan Kamalak ve ark. (2009) ve Canbolat ve ark. (2013)'nın bulguları ile uyum içerisinde olduğu görülmüştür. Bezelye kuru otu ile çalışan Bastida Garcia ve ark. (2011)'nın bildirdikleri bulgulardan daha yüksek saptanmıştır.

Yem bezelyesi silajlarına melas ilavesi dozlarına bağlı olarak ME içerikleri 8.98 ile $10.34 \mathrm{MJ} / \mathrm{kg} \mathrm{KM}$ arasında değişmiştir. En yüksek ME değeri $60 \mathrm{~g} / \mathrm{kg}$ TM düzeyinde melas ilave edilen yem bezelyesi silajında saptanmıştır $(\mathrm{P}<0.01)$. Yem bezelyesine melas katılma düzene bağlı olarak silajların $\mathrm{ME}$ içeriklerinin 
artması, OMSD'de olduğu gibi in vitro gaz üretiminin artması silajların SÇK içeriklerinin arması, hücre duvarı bileşenlerinin (NDF, ADF ve ADL) azalmasına bağlanabilir. Yem bezelyesi silajlarının ME içerikleri yem bezelyesi ile çalışan Bastida Garcia ve ark. (2011)'nın bildirdikleri ile benzer saptanmıştır. Li ve ark. (2014)' 1 ise kral otu silajina melas ilavesinin yemlerin ME düzeylerini önemli düzeyde artırdığını bildirmişlerdir. Yem bezelyesi silajı ME içeriği farklı kaba yem (yonca silajı) silajı ile çalışan ve SÇK kaynağı olarak gladiçya meyvesi kullanan Kamalak ve ark. (2009) ve Canbolat ve ark. (2013)'nın bulguları ile benzer saptanmıştır.

\section{Silajların nispi yem değeri özellikleri}

Yem bezelyesi silajlarına melas ilavesinin silajların kuru madde sindirimi (KMS), kuru madde tüketimi (KMT) ve nispi yem değerleri (NYD) üzerine etkisi saptanmış ve Çizelge 5’de verilmiştir.

Çizelge 5. Yem bezelyesi silajlarına melas ilavesinin kuru madde sindirimi (KMS), kuru madde tüketimi (KMT) ve nispi yem değerleri (NYD)'ne etkisi

\begin{tabular}{|c|c|c|c|c|c|c|}
\hline \multirow[b]{2}{*}{ Unsurlar } & \multicolumn{5}{|c|}{ Melas Katkı oranı, g/kg TM } & \multirow[b]{2}{*}{ SHO } \\
\hline & 0 & 15 & 30 & 45 & 60 & \\
\hline Kuru madde sindirimi,\% & $65.40^{\mathrm{e}}$ & $65.85^{\mathrm{d}}$ & $66.36^{\mathrm{c}}$ & $67.33^{\mathrm{b}}$ & $68.51^{\mathrm{a}}$ & 0.140 \\
\hline Kuru madde tüketimi & $3.06^{\mathrm{c}}$ & $3.13^{\mathrm{c}}$ & $3.22^{\mathrm{b}}$ & $3.25^{\mathrm{b}}$ & $3.32^{\mathrm{a}}$ & 0.025 \\
\hline Nispi yem değeri & $155.52^{\mathrm{e}}$ & $159.70^{\mathrm{d}}$ & $165.56^{\mathrm{c}}$ & $169.71^{\mathrm{b}}$ & $176.13^{\mathrm{a}}$ & 1.182 \\
\hline
\end{tabular}

${ }_{a, b, c, d, e}$ Aynı sütunda farklı harfler ile gösterilen ortalamalar arasındaki farklllıklar önemlidir ( $\left.P<0.01\right)$; SHO: standart hata ortalaması, TM: taze materyal; KMS: kuru madde sindirimi; KMT: kuru madde tüketimi; NYD: nispi yem değerleri

Yem bezelyesi silajlarına melas ilavesi silajlarının KMS'lerini önemli düzeyde etkilemiştir. Yem bezelyesi silajlarına melas ilavesi silajların KMS miktarını artırmıştır $(\mathrm{P}<0.01)$. Silajların KMS düzeyleri \%65.40 ile 68.51 arasında değişmiş olup, en yüksek \%68.51 ile $60 \mathrm{~g} / \mathrm{kg}$ TM düzeyinde melas ilave edilen yem bezelyesi silajında saptanmıştır $\quad(\mathrm{P}<0.01)$. Silajların $\mathrm{ADF}$ içeriklerinden yararlanılarak hesaplanan KMS düzeyleri ADF içeriğinin düşmesi ile artmıştır (Moore ve Undersander 2002; Canbolat ve ark., 2010). Kuru madde tüketimleri ise 3.32 ile 3.06 arasında değişmiş ve $60 \mathrm{~g} / \mathrm{kg}$ TM düzeyinde melas ilave edilen silaj grubunda daha yüksek saptanmış ve melas dozunun artışına bağlı olarak artmıştır $(\mathrm{P}<0.01)$. Yem bezelyesine melas ilavesi düzeyinin düşmesi, sindirimi yavaşlatan NDF ve ADF düzeylerinin artmasına (Çizelge 1) bağlı olarak, hayvanlarda fiziksel tokluk hissinin arması sonucu yem tüketimini sınırlanacağı bildirilmektedir (Van Soest 1994; Yavuz 2005). Araştırma verileri bu görüşü destekler nitelikte bulunmuştur. Araştırmada saptanan KMS yonca ile çalışan Adesogan ve ark. (2006) ile Canbolat ve ark. (2010) bulguları ile benzer bulunurken, KMT ise Canbolat ve ark. (2010)'nın bildirdikleri değerlerden daha düşük bulunmuştur.

Yem bezelyesi silajlarına melas ilavesi silajlarının NYD'sini önemli düzeyde etkilemiş ve melas kullanım dozuna bağlı olarak önemli artış göstermiştir $(\mathrm{P}<0.01)$. Silajların NYD'i 155.52 ile 176.13 arasında değişmiş ve $60 \mathrm{~g} / \mathrm{kg}$ TM düzeyinde melas katılan yem bezelyesi silajında en yüksek, kontrol silajında ise en düşük olarak saptanmıştır $\quad(\mathrm{P}<0.01)$. Yem bezelyesi silajlarına melas ilavesi sindirimini zor olan hücre duvarı bileşenlerinin (NDF ve ADL) azalmasına yol açarak silajların NYD'ni olumlu etkilemiştir. Yem bezelyesi silajlarında saptanan NYD, tam çiçeklenme dönemindeki yonca otu için kabul edilen 100 değeri (Moore ve Undersander 2002) ile kıyaslandığında, tüm yem bezelyesi silajlarının yüksek kaliteli kaba yemler arasında oldukları söylenebilir. Yem bezelyesi silajlarında saptanan NYD bezelye otu ile çalışan Kocer ve Albayrak (2012) ve Yavuz (2017)'nin bulguları ile benzer saptanmıştır.

Yem bezelyesi silajlarında saptanan NYD farklı kaba yem (yonca silajı) silajı ile çalışan ve SÇK kaynağı olarak üzüm posası kullanan Canbolat ve ark. (2010)'nın bildirdiği değerden daha yüksek bulunmuştur.

\section{SONUÇ}

Sonuç olarak, bu araştırma silolanması güç olan yem bezelyesinden kaliteli silaj elde etmek ve silaj kalitesini artırmak için düzenlenmiştir. Bu amaçla yem bezelyesinin silolanma özelliğini artırmak için yapısında az olan suda çözünebilir karbonhidrat (SÇK) içeriğini artırmak için melas kullanılmıştır. Bu amaçla kullanılan melasın yem bezelyesi silajlarının ham besin maddeleri, fermantasyon özelliklerini, in vitro gaz üretimi ve nispi yem değeri özelliklerini geliştirdiği saptanmıştır. Araştırma verileri incelendiğinde tüm melas dozlarının yem bezelyesi silajlarının kalitesine katkı sağlamasına rağmen, en uygun melas dozunun 45 ile $60 \mathrm{~g} / \mathrm{kg}$ TM arasinda olduğu sonucuna varılmıştır.

\section{KAYNAKLAR}

Adesogan AT, Sollenberger LE, Moore JE 2006. Forage quality. In, Chambliss CG (Ed): Florida forages handbook. Univ of Florida, Cooperative Extension Services. 
Alçiçek A, Karaayvaz K 2003. Sı̆̆ır besisinde mısır silajı kullanımı, Animalia, 20(3): 18-76.

AOAC 2000. Official Methods of Analysis, 17th Edition, Association of Official Analytical Chemist International, Washington DC.

Ay U, Altın M, Şen C 2017. Kırklareli koşullarında yem bezelyesi (Pisum arvense 1.)-buğday'ın (Triticum aestivum L.) farklı karışım oranları ve biçim zamanlarının ot verimi ve kalitesine etkisi, Tekirdağ Ziraat Fakültesi Dergisi, 14 (3): 80-85.

Barker SB, Summerson WH 1941. The colorimetric determination of lactic acid in biological material, Journal of Biological Chemistry, 138: 535-554.

Bastida Garcia JL, González Ronquillo M, Dominguez VIA, Romero BJ, Castelán OO 2011. Effect of field pea (Pisum sativum L.) level on intake, digestion, ruminal fermentation and in vitro gas production in sheep fed maintenance diets, Animal Science Journal, 82: 654-662.

Blagojević,M, Đorđević N, Bora D, Marković J, Vasić T, Milenković J, Petrović M 2017. Determination of green forage and silage protein degradability of some pea (Pisum sativum L.) toat (Avena sativa L.) mixtures grown in Serbia, Tarım Bilimleri Dergisi, 23(4): 415-422.

Boğa M 2014. Zeytinyağı yan ürünlerinin ruminant beslemede kullanım olanakları, Türk Tarım-Gıda Bilim ve Teknoloji Dergisi, 2(3): 137-143.

Bolsen KK, Ashbell G, Weinberg ZG 1996. Silage fermentation and silage additives, AsianAustralasian Journal of Animal Sciences, 9(5): 483493.

Borreani G, Cavallarin L, Antoniazzi S, Tabacco E 2006. Effect of the stage of growth, wilting and inoculation in field pea (Pisum sativum L.) silages. I. Herbage composition and silage fermentation, Journal of the Science of Food and Agriculture, 86: 1377-1382.

Canbolat Ö, Kalkan H, Filya İ 2013. Yonca silajlarında katkı maddesi olarak gladiçya (Gleditsia Triacanthos) kullanılma olanakları, Kafkas Üniversitesi Veteriner Fakültesi Dergisi, 19(2): 291-297.

Canbolat Ö, Kalkan H, Karaman Ş, Filya İ. 2010. Üzüm posasının yonca silajlarında karbonhidrat kaynağı olarak kullanılma olanakları. Kafkas Üniversitesi Veteriner Fakültesi Dergisi, 16(2): 269-276.

Dubois M, Giles KA, Hamilton JK, Rebes PA, Smith F 1956. Colorimetric method for determination of sugars and related substances, Analytical Chemistry, 28: 350-356.

Filya I, Ashbell G, Weinberg ZG, Hen Y 2001. Hücre duvarını parçalayıcı enzimlerin yonca silajlarının fermantasyon özellikleri, hücre duvarı kapsamı ve aerobik stabiliteleri üzerine etkileri, Tarım Bilimleri Dergisi, 7(3): 81-87.
Göçmen N, Özaslan Parlar A 2017. Yem bezelyesi ile arpa, yulaf ve tritikale karışım oranlarının belirlenmesi, Çanakkale Onsekiz Mart Üniversitesi Ziraat Fakültesi Dergisi, 5(1): 119-124.

Jian W, Lei C, Xian-jun Y, Gang G, Jun-feng LI, Yunfeng B, Tao S 2017. Effects of molasses on the fermentation characteristics of mixed silage prepared with rice straw, local vegetable byproducts and alfalfa in Southeast China, Journal of Integrative Agriculture, 16(3): 664-670.

Kaiser AG 2004. Silage additives. Chapter 7 in Successful Silage. Kaiser AG, Piltz JW, Burns HM, Griffiths NW. (eds). Dairy Australia and New South Wales Department of Primary Industries. New South Wales, Australia.

Kamalak A, Aydın R, Bal MA, Atalay AI 2009. Gladiçya meyvesinin katkı maddesi olarak yonca silajında kullanımı, Tübitak, Proje No: 1070 401. 167.

Kocer A, Albayrak S 2012. Determination of forage yield and quality of pea (Pisum Sativum L.) mixtures with oat and barley, Turkish Journal of Field Crops, 17(1): 96-99.

Li M, Zi X, Zhou H, Hou G, Cai Y 2014. Effects of sucrose, glucose, molasses and cellulase on fermentation quality and in vitro gas production of king grass silage, Animal Feed Science and Technology, 197: 206-212.

Limin Kung JR, Tung RS, Maciorowski KG, Buffum K, Knutsen K. Aimutis WR. 1991. Effects of plant cellwall-degrading enzymes and lactic acid bacteria on silage fermentation and composition, Journal of Dairy Science, 74(12): 4284-4296.

Limin Kung JR, Stokes MR, Lin CJ 2003. Silage additives. D.R. Buxton, R.E, Muck, H, Harrison (Eds.), Silage science and technology (Agronomy Series No. 42), American Society of Agronomy, Madison, 305-360.

McDonald P, Henderson AR, Heron SJE 1991. The Biochemistry of Silage. $2^{\text {nd }}$ edn. Chalcombe Publications; Bucks, England.

Menke K, Raab L, Salewski A, Steingass H, Fritz D, Schneider W 1979. The estimation of the digestibility and metabolisable energy content ofruminant feeding stuffs from the gas production when they are incubated with rumen liquor, Journal of Agricultural Science, 93(1): 217-222.

Menke K, Steingass H 1988. Estimation of the energetic feed value from chemical composition and in vitro gas production using rumen fluid, Animal Research and Development, 28: 7-55.

Moore JE, Undersander DJ 2002. Relative Forage Quality: An alternative to relative feed value and quality index. Proceedings $13^{\text {th }}$ Annual Florida Ruminant Nutrition Symposium, 16-32. 10-11 January, Gainesville.

Ni K, Wang F, Zhu B, Yang J, Zhou G, Pan Y, Tao Y, Zhong J 2017. Effects of lactic acid bacteria and 
molasses additives on the microbial community and fermentation quality of soybean silage, Bioresource Technology, 238: 706-715.

Rohweder DA, Barnes RF, Jorgensen N 1978. Proposed hay grading standards based on laboratory analyses for evaluating quality. Journal of Animal Science, 47(3): 747-759.

Rooke JA, Hatfield RD 2003. Biochemistry of Ensiling. Publications from USDA-ARS / UNL Faculty, 1399.

SAS (Statistical Analysis Systems) 2004. 'SAS procedures guide. Release 9.1.' (SAS Institute Inc.: Cary, NC)

Seale DR, Pahlow G, Spoelstra SF, Lindgren S, Dellaglio F, Lowe JF 1990. Methods for the microbiological analysis of silage, Proceeding of The Eurobac Conference, 147, Uppsala.

Tjandraatmadja M, Norton B, Mac W, Rae IC 1994. Ensilage of tropical grasses mixed with legumes and molasses, World Journal of Microbiology and Biotechnology, 10(1): 82-87.

Tyrolová Y, Výborná A 2011. The effects of wilting and biological and chemical additives on the fermentation process in field pea silage, Czech Journal of Animal Science, 56(10): 427-432.

Umana R, Staples CR, Bates DB, Wilcox CJ, Mahanna WC 1991. Effects of a microbial inoculants and (or) sugarcane molasses on the fermentation, aerobic stability, and digestibility of bermudagrass ensiled at two moisture contents, Journal of Animal Science, 69(11): 4588-4601.

Van Soest PJ 1994. Nutritional ecology of the ruminant, $2^{\text {nd }}$ Edition, Cornell University Press, Ithaca, 476.

Van Soest PJ, Robertson JD, Lewis BA 1991. Methods for dietary fibre, neutral detergent fibre and nonstarch polysaccharides in relation to animal nutrition, Journal of Dairy Science, 74(10): 35833597.

Wamatu J, Alkhtib A, Abate D, Kemal SA, Rischkowsky B 2017. Nutritive value of field pea (Pisum sativum L.) straw as influenced by variety, season, botanical fractions and urea pretreatment, Animal Feed Science and Technology, 225: 54-61.

Yavuz M 2005. Bazı ruminant yemlerinin nispi yem değeri ve in vitro sindirim değerlerinin belirlenmesi, Gaziosmanpaşa Üniversitesi Ziraat Fakültesi Dergisi, 22(1): 97-101.

Yavuz T 2017. Farklı Biçim Zamanlarının Yem Bezelyesi (Pisum sativum L.) ve Yulaf (Avena sativa L.) Karışımlarında ot verim ve kalitesi üzerine etkileri, Tarla Bitkileri Merkez Araştırma Enstitüsü Dergisi, 26(1): 67-74. 